\author{
T. H. Bondaruk, \\ DSc in Economics, Professor, \\ Head of the Department, \\ E-mail: bondaruk23@ukr.net \\ Researcher ID: Q-5166-2016, \\ ORCID: https://orcid.org/0000-0001-9410-6428; \\ L. Ye. Momotiuk, \\ DSc in Economics, Professor, \\ First Vice-rector on scientific and pedagogical work, \\ E-mail:momotyuk_le@ukr.net \\ ResearcherID: F-4873-2018, \\ ORCID: https://orcid.org/0000-0002-0445-5948, \\ National Academy of Statistics, Accounting and Audit; \\ O. S. Bondaruk, \\ $P h D$ in Economics, \\ Director of LLC "Oleksandrivska Pharmaceutical Company", \\ E-mail: bondaruk999@ukr.net \\ Researcher ID: H-7703-2017, \\ ORCID: https://orcid.org/0000-0002-3472-9516
}

\title{
Budget Security as Factor of Economic Development of the State
}

A system analysis of the core threats to the budgetary security of the state shows that the current performance of the budgetary system in Ukraine was formed under the pressure of destructive external and internal risks aggravating the budgetary security problem. The article's objective is to deepen theoretical and methodological foundations for the assessment of core threats to the budgetary security of the state.

It is demonstrated that the occurrence of external and internal threats to the budgetary security is characterized by the following tendencies: high level of GDP redistribution through the budgetary system; the growing figures of the total public debt, the government guaranteed debt and the payments to service and repayment of the public debt in Ukraine; the persisting high deficit of the public budget; high level of centralization of the budgetary funds.

It is substantiated that the execution of budget revenues involves two main dimensions of risk activities, which are the threats related with the proceeding of taxes and other categories of obligatory payments to the budget, and the administrative threats stemming from the existing system of tax administering. The impact of the first group of threats can be minimized by building up a rational budgetary system with the optimal level of fiscal burden. Minimization of the impact from the second group of threats will enable for the effective work of government bodies charged with administering and control.

The factors that cause risks and threats of budget losses resulting from failures in the budget revenues administration system are determined: risks which occurrence will result in the budget revenues never reaching the expected levels due to the inefficiency of forecasting and planning of budget revenues and failures in the routine operation process, first and foremost when mobilizing payments to the budget; risks of the excessive costs with the occurrence of which the costs for guaranteeing the projected figures of budget revenues by revenue category will exceed the economically viable ones; risks of the violation of the law, and risks of budget revenues administering per se.

Key words: budgetary security, threats to budgetary security, budgetary system, public debt, deficit to public debt.

The latest political and economic events have become the destructive factors that have undermined the stability of Ukraine's economy in general and the financial system of the state in particular. Since the budgetary system is a reflection of socio-economic processes in the state, the indicators of the state budget system are characterized by high volatility and unpredictability of the dynamics, which complicates their forecasting due to the high level of uncertainty, and this tendency continues to intensify and impedes the implementation of progressive changes in the economy. This leads to the need for new approaches to the analysis of the state of the budget system and the development of qualitatively other levers of influence on the state of budgetary security.

(C) T. H. Bondaruk, L. Ye. Momotiuk, O. S. Bondaruk, 2020 
The study of the peculiarities of the development of the budget system of Ukraine in the context of providing budget security at the present stage of the implementation of reforms becomes urgent, since its guarantee is one of the key tasks of the state in implementing budget policy that would ensure the goals of socio-economic development of the state and meet national interests. The importance of problems related to fiscal security, which is a prerequisite for ensuring positive changes in the national economy, and the peculiarities of the influence of budget elements on the increase of the effectiveness of the mechanisms of economic security of the state, determines the relevance of the research topic.

The issues of financial and budgetary systems and their safety are of great importance in the research of such scholars as O. Vlasiuk, L. Shemaieva, L. Lohar, N. Koren, V. Fedosov, S. Yurii and others. Most scientific works of the named researchers are aimed at revealing general tendencies of functioning of economic security and budget system. Despite the attention of scientists to the problems of the state budget and economic security of the state, many outstanding issues related to the definition of budgetary risks and minimization of their impact on fiscal security remain, which will reinforce the need for further research in this area.

The purpose of the article is to deepen theoretical and methodological principles of the assessment of main threats to guarantee the state budgetary security.

The study of the assessment of main threats to ensure the state budget security was carried out during the period from 2000 to 2016, forecast data for some indicators up to 2020 was calculated. To achieve the purpose of thestudy we used the fundamental, theoretical positions and principles of modern and classical economic theory, the theory of system analysis, works of Ukrainian and foreign scientists on issues of economic security and security of budget system. We applied general scientific and special methods for the purpose to study of social and economic processes and phenomena, namely: induction and deduction, generalization - to clarify the categorical and conceptual apparatus; system analysis and synthesis, statistical, correlation analysis to assess the current state of formation of main threats to the state budgetary security, the disclosure of their development trends; logical generalization - to study sources of threats to budgetary security; graphic method - when visualizing the main results.

The statistical and factorial basis of the study are normative and legal acts, scientific works of Ukrainian and foreign economists on the study of problems of economic security and budgetary system, reported data of the Ministry of Finance of Ukraine, the State Treasury Service of Ukraine; statistical materials of the State Statistics Service of Ukraine; own analytical work of authors and electronic resources of the Internet.

Budget security as a significant factor in the socioeconomic development of the state is one of the decisive criteria for the effectiveness of fiscal policy. Budget security expresses the ability of the state, with the help of budgetary levers, to fulfill its functions and tasks taking into account individual, corporate and social interests [1]. Therefore, the provision of budgetary security of the state is part of the system of tasks of forming an effective budget policy and achieving strategic socio-economic priorities. Increasing attention to the problems of budgetary security in Ukraine is due to the dynamics of social processes both in the global and national dimensions [2].

Since fiscal security is a key component of financial security, let's consider the dynamics of the integral indicator of Ukraine's financial security. According to actual and projected calculations of the general state of economic security of Ukraine, the integral indicator of Ukraine's financial security level in 2000, 2001, 2004, 2014-2016 was in the critical area. According to the forecasted calculations by 2020, Ukraine's financial security is at the lower level (Fig. 1, calculated by the authors calculated by the authors on the basis of the data [3]).

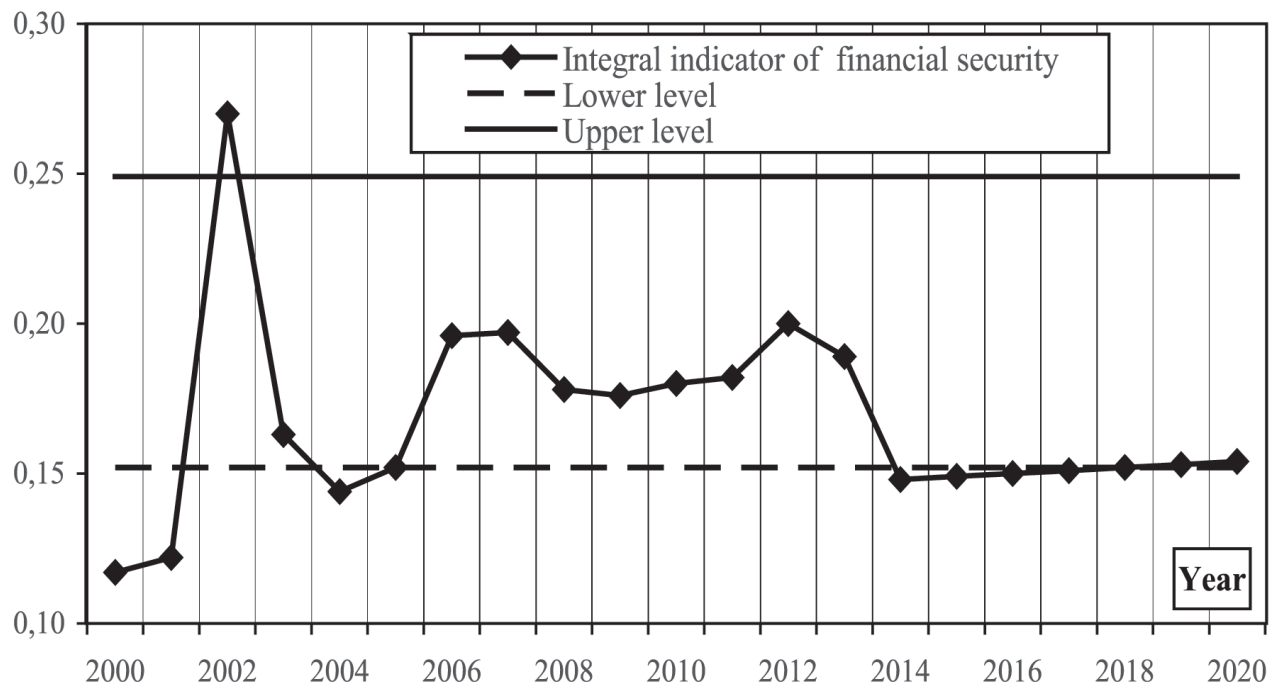

Fig. 1. Dynamics of the integral indicator of Ukraine's financial security level 
Positive dynamics of social and economic processes and the ability to reduce the negative impact of numerous risks and threats to the financial security of the state, which are exacerbated not only during the crisis, but also during the period of economic reform, should provide budgetary tools.

Ensuring budget security is one of the prerequisites for achieving strategic socio-economic priorities of state development. Threats to the budgetary security of the state, expressing the potential for negative influence, are of a subjective nature, since they are largely dependent on budgetary decisions and the reconciliation of public interests.

The main factor in the formation of threats in fiscal policy is the inconsistency of public needs and the limited resources of the state. The emerging threats are determined by the content of the reproductive processes of the subjects of the budget legal relations, the degree of coordination of their interests, and, consequently, the functional determinism of budget policy, the principles of budget formation and the equivalence of the distribution of its funds at the levels of the budget system [1].

The current state of the budget system of Ukraine was shaped by a number of destructive external and internal challenges that exacerbated the issue of ensuring budgetary security. Challenges caused by external and internal threats in the development of the budget system are characterized by the following trends [4].

There is a high level of GDP redistribution through the budget system (Fig. 2, 3 calculated by the authors on the basis of the data [5]). The share of consolidated budget revenues in GDP in 2017 and 2019 amounted to 34.09 and $32.45 \%$ (compared to $29.0 \%$ in 2013), indicating an increase in the level of GDP redistribution through the budget system. In 2017, the share of consolidated budget expenditures in GDP was $35.47 \%$ - the highest figure for the last six years (in 2016 - 35.11\%, in 2018 - 35.13\%,). In 2019, the share of consolidated budget expenditures in GDP was $34.47 \%$.

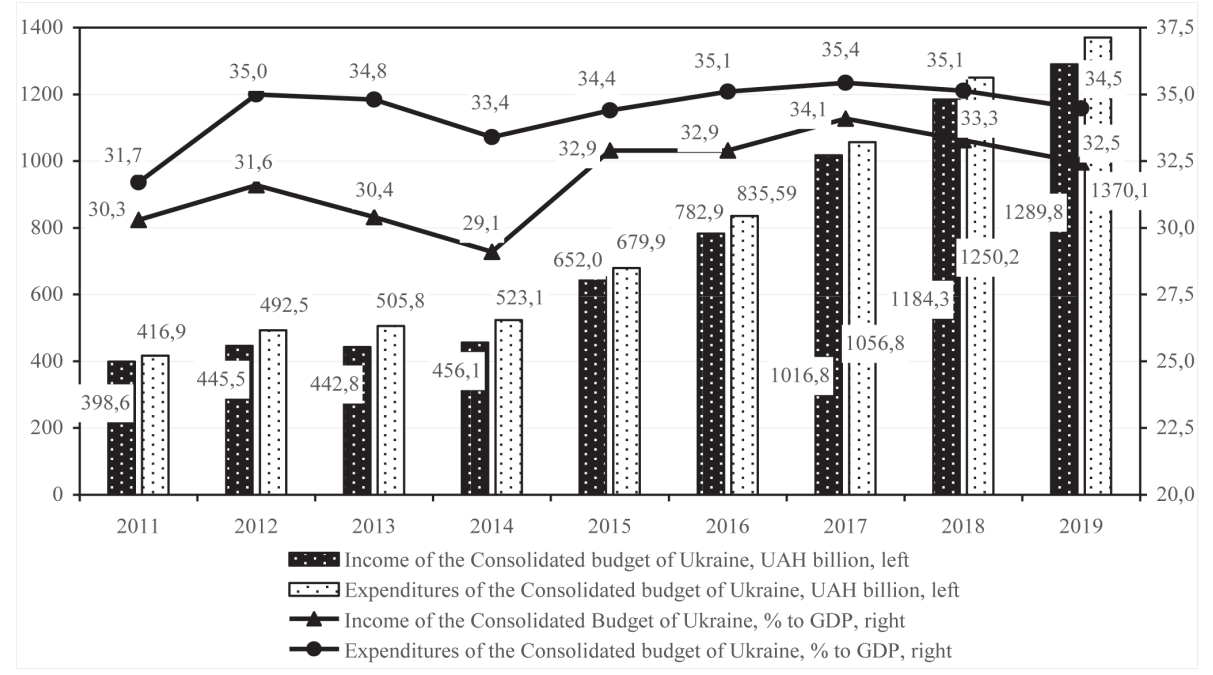

Fig. 2. Dynamics of income and expenditures of the Consolidated Budget of Ukraine

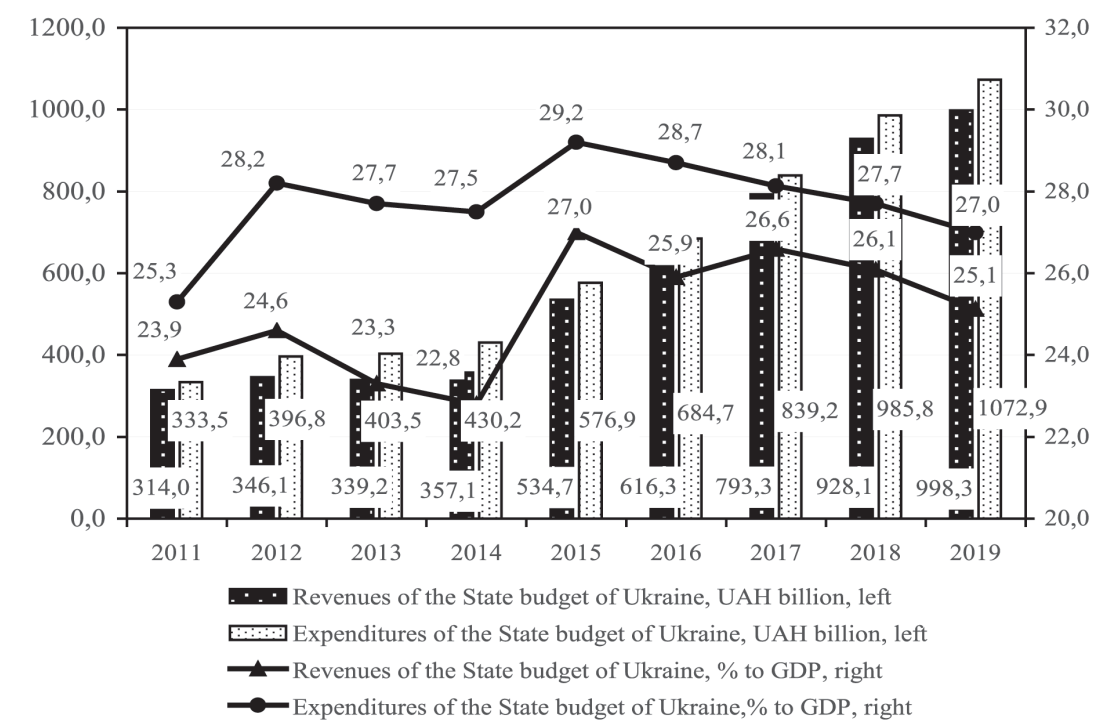

Fig. 3. Dynamics of revenues and expenditures of the State Budget of Ukraine and their share in GDP 
The volume of expenditures of the consolidated budget of Ukraine in 2016 (when official dollar rate was $24.78 \mathrm{UAH}$ ) amounted to 33,69 billion USD, which is twice the respective indicator of 2011, revenues of the consolidated budget of Ukraine also increased in 2016 almost twice as compared to 2011.

Threats to budget expenditures arise at each stage of the budget process, which may include shortcomings and omissions of organizational, regulatory and financial nature, as well as the inadequate execution by the chief spending unit manager of control functions and functions of management of budget funds, namely: lack of timeliness approval of passports of budget programs and the order of using budget funds; non-compliance with the order of using budget funds; shortcomings in the organization of accounting; untimely distribution of open allocations; insufficient control by the main spending units for the activities of lower level managers and recipients of budget funds; untimely and poorly prepared reports on the implementation of budget program passports, etc.

The risk of growth in payments for servicing and repayment of public debt is a significant factor, which for a long time raises problems in the field of public finances and has an impact on fiscal security.

The trend towards excessive increase in debt burden has become a characteristic challenge of recent years: if in 2013 the level of debt was 33.0\% of GDP, then in 2014 the corresponding indicator exceeded the thresholds and reached $69.3 \%$ in 2016 In relation to GDP, the state and state-guaranteed debt amounted to $79.3 \%$ (the ratio of public debt to nominal GDP was 67.3\%) [7], and according to the results of 2016, in relation to GDP, the state and stateguaranteed debt increased by $0.7 \mathrm{pp}$ and. amounted to $81.0 \%$, its total amount amounted to 1929.8 billion $\mathrm{UAH}$.

In 2016, the amount of state and state-guaranteed debt of Ukraine increased by 357.6 billion UAH, while in dollar terms it increased by $\$ 5.5$ billion. As of January 1, 2017, the state and state-guaranteed debt of Ukraine amounted to 1929.8 billion UAH ( $\$ 70.97$ billion), including: state and guaranteed by the state external debt UAH 1249 billion $(\$ 45.6$ billion), which is $64.3 \%$ of the total amount of state and guaranteed state debt; state and guaranteed by the state domestic debt - UAH 689.7 billion $(\$ 25.4$ billion), which is $64.3 \%$ of the total state and stateguaranteed debt. As of January 1, 2020, the state and state-guaranteed debt of Ukraine amounted to UAH 1,998.3 billion.

Using trend analysis, we forecast the trend of the dynamics of Ukraine's public debt relative to GDP (see Fig. 4, calculated by the authors on the basis of the data of [6]).

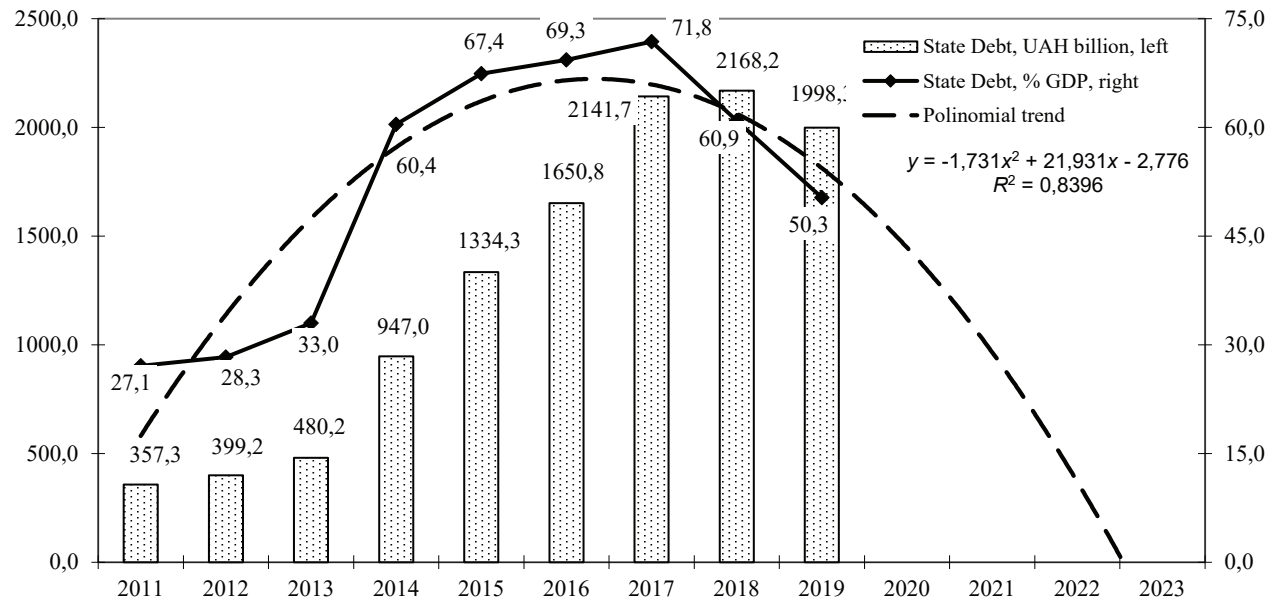

Fig. 4. Polynomial trend of changes in the dynamic of Ukraine's public debt relative to GDP

As the Fig. 4 testifies, the indicators of Ukraine's sovereign debt have a downward trend. Relative indicators of the state debt in the medium-term showed a downward dynamics and showed an increase in the degree of solvency of the state.

The growth rate of external debt significantly exceeds the growth rates of domestic borrowings, which indicates the unsatisfactory state of the internal potential of the monetary system of the state.

The Association Agreement between Ukraine and the EU provides for cooperation in the field of public finance management aimed at ensuring the development of fiscal policy and is based on international standards.
In the member countries of the euro area, according to the Maastricht criteria, the size of the gross debt of the government should not exceed $60 \%$ of GDP [8]. The critical level of public debt to GDP at the level of $60 \%$ for state and guaranteed debt was fixed in the Budget Code of Ukraine. The actual amount of Ukraine's public debt (81\%) significantly exceeds the officially established ceiling (60\%), but similar situation is observed in 19 of the EU-28 countries. A significant increase in Ukraine's debt burden in recent years has led to a high level of government budget deficits in Ukraine.

The deficit of the state budget of Ukraine in 2016 amounted to 68.4 billion UAH, which is $2.9 \%$ of GDP 
(table 1, calculated on the basis of the data of [10]). The indicator corresponds to the Maastricht criteria and the requirements of the IMF Memorandum, besides, this indicator is below the level of 2012-2014 (3.7-5.0\%),

but significantly exceeds the level of 2015 (1.6\%).

Table 1

Dynamics of the deficit of the Consolidated and State budgets of Ukraine in 2011-2019

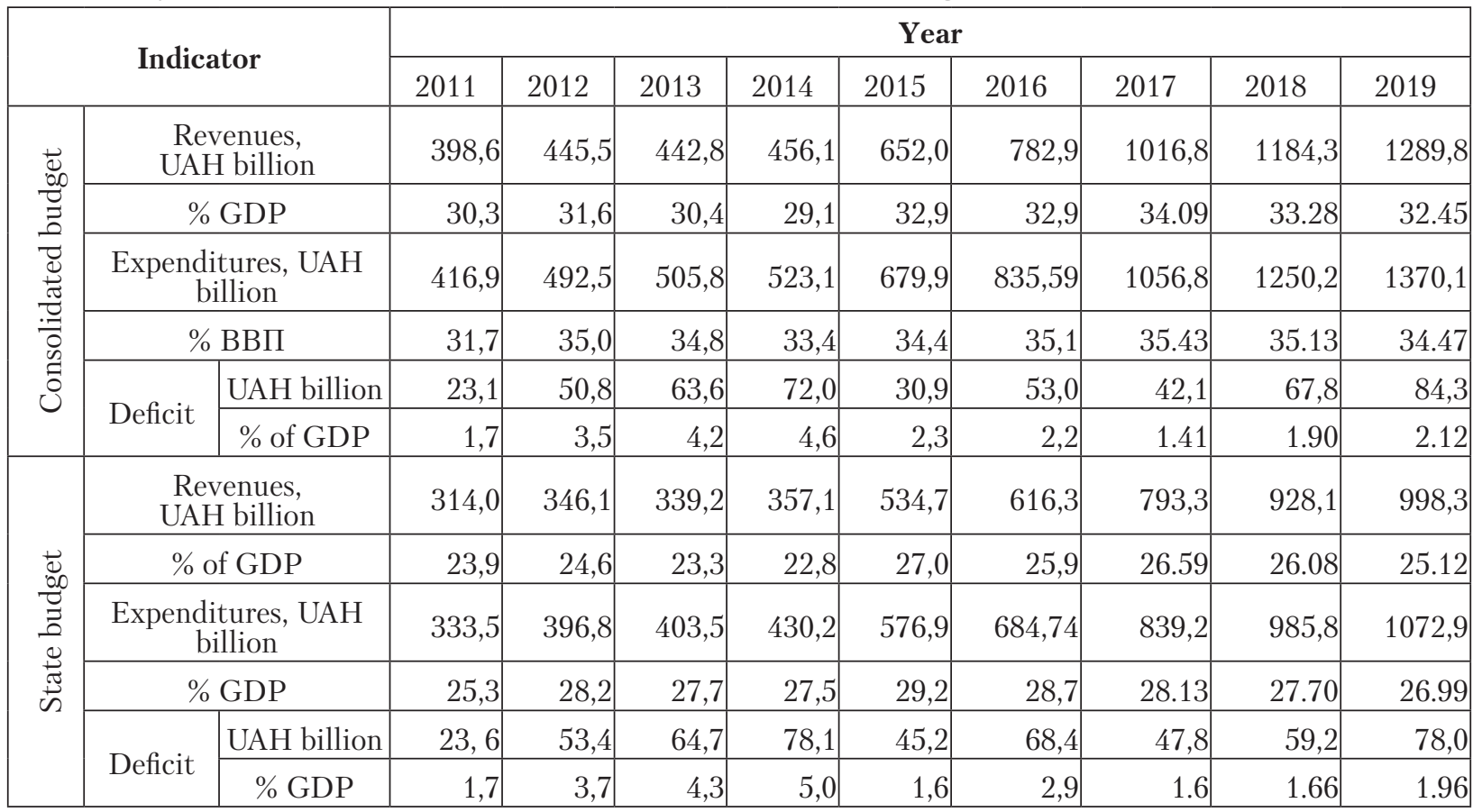

The increase of the state budget deficit from $1.6 \%$ of GDP in 2017 to $1,96 \%$ of GDP in 2019 is conditioned, in particular, by the need to pay off debt obligations, ensuring adequate level of financing of the security sector and state defense, ensuring social protection functions of citizens (Koren N. V., 2015). The growth of the budget deficit has also led to a reduction in the EBU revenues to the Pension Fund of Ukraine, which has led to the need to increase its budget support.

The sources of financing the budget deficit are privatization proceeds, as well as government borrowing.
Each year, the indicators of privatization receipts to the budget were insignificant, the last two years - less than one percent of the projected figure (Fig. 5, calculated on the basis of the data of the State Treasury Service of Ukraine [10]). So from planned in 201917.1 billion UAH of the proceeds from privatization came to only 536 million UAH, in 2015 it received 151.5 million UAH of the planned UAH 17.0 billion, in $2014 \mathrm{UAH}$ 0.5 billion came of the planned 17 billion UAH, in 2013 UAH 1.5 billion came of the planned 10.9 billion UAH.

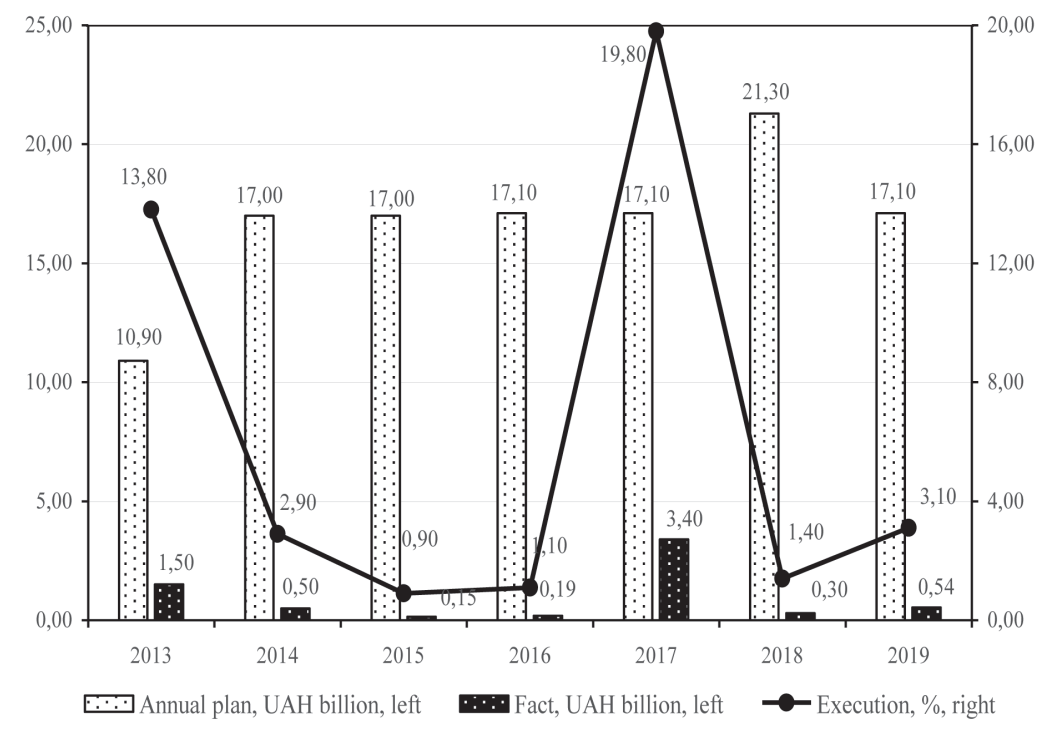

Fig. 5. Proceeds from privatization to the State Budget of Ukraine 
Due to the unfavorable investment climate, which reduces the demand and price of privatization objects, there is a high risk of non-receipt of funds in the state budget of Ukraine planned for 2020 in the amount of 12 billion UAH In connection with this, financing of the budget deficit through the additional issue of government securities is used, which leads to an increase in public debt. In a significant debt burden and maintaining a high level of budget deficits, this factor will negatively affect the decision of the tasks of guaranteeing budget security.
Threats to the revenue side of the budget are threats of lack of revenue and budget commitments. Revenues of the consolidated and state budgets grew at a rapid pace during the whole period of 2011-2019, in 2016 they increased almost twice as compared to 2011, and in 2016 the consolidated and state budget revenues grew in comparison with 2014 amounted to more than $70 \%$ (Fig. 6, calculated on the basis of the data of the State Treasury Service of Ukraine [10]).

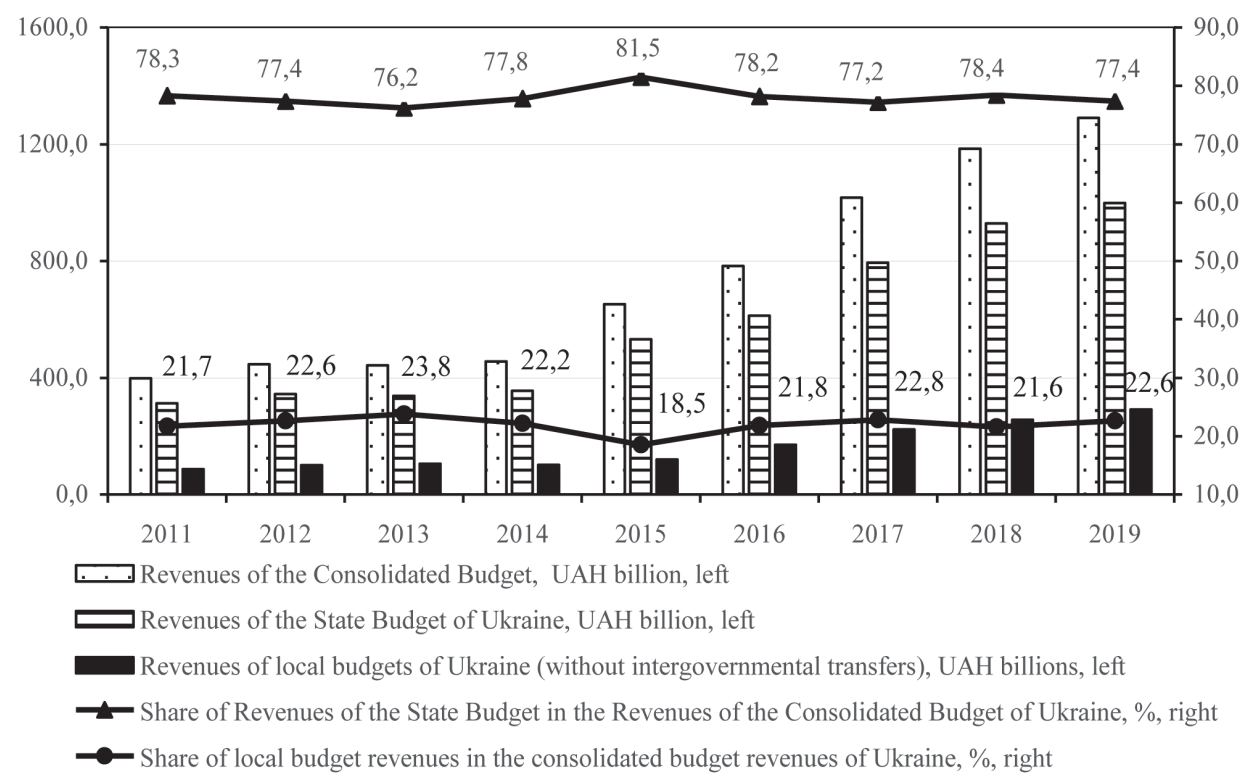

Fig. 6. Dynamics of revenues of consolidated, state and local budgets of Ukraine

However, if in 2015 the increase in revenues was mainly due to inflation-devaluation effects and tax changes at the beginning of the year, then in 2016 - mainly with improved tax administration and a certain stabilization of the economic situation.

In 2016, the annual plan for the revenue side of the consolidated budget was implemented at $100.2 \%$. The revenue part of the consolidated budget was UAH 782.7 billion in 2016, and the revenue part of the state budget, taking into account intergovernmental transfers, amounted to UAH 616.3 billion.

At the same time, tax revenues, in contrast to the reduction in 2013 , increased by $3.8 \%$, which is due both to tax innovations from the second half of 2014, and with inflationary effects. The reduction of non-tax revenues in 2014 amounted to $5.3 \%$, which is in particular due to a decrease in transfers from the National Bank (by 19.4\%).

There are two main aspects of risk activity in providing budget revenues. Threats are related to the flow of taxes and other types of compulsory payments and directly affect the behavior of their payers (minimizing the impact of this group of risks and threats is aimed at building a rational budget system at an optimal level of fiscal burden) and the risks and threats posed by the existing system administration of budget revenues (managerial risks, reflect the effective activity of administration and control bodies) [9].

The risks and threats of budget losses as a result of violations in the budget revenue management system may be due to the following factors: risks in implementing which budget revenues will not reach the projected amounts that may be caused by the ineffectiveness of such components of budget management as forecasting and planning budget revenues, in particular tax revenues; violations in the process of operational work - the mobilization of payments to the budget [4].

Risks of overcapacity, in the case of which the costs of ensuring the forecast amounts of revenues to budgets for certain types of income will exceed the economic expediency. These risks are determined by the current (proposed) rules of procedure for administering revenues.

The threats posed by the risks of managing the revenue part of the budget include the risks of violations of the budget and tax laws and the risks of administering budget revenues. The risk of violations of budgetary and tax legislation by public servants is 
characterized by the possibility (probability) of abuse and corruption by government officials, resulting in possible loss of budget revenues. The risks to the revenue administration process include the effect of operational processes, objective or subjective factors, ineffective management and violations of fiscal and tax laws, which leads to an increase in budget losses.

Conclusions. By analyzing the risks and threats to the state budget security, it has been established that they are characterized by such tendencies. First, the high level of GDP redistribution through the budget system remains. In 2019, the share of consolidated budget revenues in GDP amounted to $32.45 \%$, while the share of consolidated budget expenditures in GDP was $34.47 \%$. Secondly, it was dangerous not only to increase the total amount of state and state-guaranteed debt of Ukraine, but also a significant increase in budget expenditures to finance its servicing and repayment. Forecast calculations of the trend of changes in the expenditure of the state budget of Ukraine for repayment and servicing of the state debt show an upward trend, which is confirmed by calculations of their forecast indicators by 2020 , which also indicate an increase in threats to the budget security of Ukraine. Third, the high level of the state budget deficit remains, which is expected to increase from $1.6 \%$ of GDP in 2015 to $2.9 \%$ of GDP in 2016, in particular, the need to pay off debt obligations, to finance expenditures on defense, social protection and social security. Fourth, the threat of non-fulfillment of the plan of incomes and expenditures of the consolidated, state and local budgets is caused by the risks of management and risks of non-fulfillment of planned indicators.

Future studies are expected to be devoted to summing up the set of external and internal factors that have impact on the mechanism of budgetary security in Ukraine, cause the occurrence of budgetary risks and threats and worsen the budgetary security situation.

\section{References}

1. Koren, N. V. (2015). Vyklyky ta zahrozy biudzhetnii bezpetsi na etapi suspilnykh transformatsii [Challenges and threats to budgetary security at the stage of social transformations]. Naukovyi visnyk Khersonskoho derzhavnoho universytetu. Seriia "Ekonomichni nauky" - Scientific Herald of Kherson State University. Economic Sciences, 14, 3, 130-133 [in Ukrainian].

2. Pikhotskyi, V. (2010). Efektyvnist fiskalnoi polityky yak instrumentu sotsialno-ekonomichnoho rozvytku Ukrainy [Effectiveness of fiscal policy as an instrument of socio-economic development of Ukraine]. Finansy Ukrainy - Finance of Ukraine, 3, 30-37. [in Ukrainian].

3. General condition of economic security of Ukraine. (2010). wwrw.me.gov.ua. Retrieved 12.01 .2012 from http://www.me.gov.ua/ [in Ukrainian].

4. Bondaruk, O. (2017). Analiz biudzhetnykh zahroz ta yikh vplyvu na finansovu bezpeku Ukrainy [Analysis of budget threats and their impact on financial security of Ukraine]. Mizhnarodni vidnosyny. Seriia "Ekonomichni nauky" - International Relations. Part "Economic Sciences", 10. Retrieved from http://journals. iir.kiev.ua/index.php/ec_n/article/view/3275 [in Ukrainian].

5. Ofitsiinyi vebsait Ministerstva finansiv Ukrainy [Official website of the Ministry of Finance of Ukraine]. mof.gov.ua . Retrieved from https://mof.gov.ua/uk [in Ukrainian].

6. Ofitsiine Internet-predstavnytstvo Natsionalnoho banku Ukrainy [Official website of the National Bank of Ukraine]. bank.gov.ua. Retrieved from https://bank.gov.ua/control/uk/index [in Ukrainian].

7. Vlasiuk, O. S., Shemaieva, L. H., \& Londar, L. P. (2016). Borhova stiikist yak stratehichnyi napriam pidoyshchennia rivnia finansovoi bezpeky [Debt sustainability as a strategic direction of the level of financial security increasing]. Kyiv: NISD [in Ukrainian].

8. Zubenko, V. V., Samchynska, I. V., Rudyk, A. Yu., Shapoval, T. A., Korniyenko, A. I., Bohdan, T. P. et al. (2017). Biudzhetnyi monitorynh: Analiz vykonannia biudzhetu za 2016 rik. IBSED, Proekt "Zmitsnennia mistsevoi finansovoi initsiatyvy (ZMFI-II) vprovadzhennia" [Budget Monitoring. Analysis of budget execution in 2016. IBSER. Municipal Finance Strengthening Initiative Project Roll-out (MFSI-II)]. Kyiv: USAID [in Ukrainian].

9. Fedosov, V., \& Yurii, S. (Eds.). (2012). Biudzhetna systema [Budget system]. Kyiv: Tsentr uchbovoi literatury; Ternopil: Economichna dumka [in Ukrainian].

10. Ofitsiinyi vebsait Derzhavnoi kaznacheiskoi sluzhby Ukrainy [Official website of the State Treasury of Ukraine]. werero.treasury.gov.ua. Retrieved from http://www.treasury.gov.ua/main/uk/index [in Ukrainian]. 


\author{
Т. Г. Бондарук, \\ доктор економічних наук, професор, \\ завідувач кафедри, \\ E-mail: bondaruk23@ukr.net \\ Researcher ID: Q-5166-2016, \\ ORCID: https://orcid.org/0000-0001-9410-6428; \\ л. Є. Момотюк, \\ доктор економічних наук, професор, \\ перший проректор з науково-педагогічної роботи, \\ E-mail: momotyuk_le@ukr.net \\ ResearcherID: F-4873-2018, \\ ORCID: https://orcid.org/0000-0002-0445-5948; \\ Національна академія статистики, обліку та аудиту; \\ O. С. Бондарук, \\ кандидат економічних наук, \\ директор ТОВ “Олександрівська фармацевтична компанія", \\ E-mail: bondaruk999@ukr.net \\ Researcher ID: H-7703-2017, \\ ORCID: https://orcid.org/0000-0002-3472-9516
}

\title{
Бюджетна безпека як фактор економічного розвитку держави
}

Системний аналіз ключових загроз бюджетній безпеці держави показав, що сучасний стан бюджетної системи України сформувався під впливом деструктивних зовнішніх і внутрішніх ризиків, які загострили питання забезпечення бюджетної безпеки. Метою статті є поглиблення теоретико-методичних засад оцінки ключових загроз гарантування бюджетної безпеки держави.

Доведено, що виникнення зовнішніх і внутрішніх загроз бюджетній безпеці характеризується такими тенденціями: високий рівень перерозподілу валового внутрішнього продукту через бюджетну систему; зростання як загальної суми державного та гарантованого державою боргу України, так і обсягу платежів з обслуговування та погашення державного боргу; збереження високого рівня дефіциту державного бюджету; високий рівень централізації бюджетних коштів.

Обгрунтовано, що при забезпеченні виконання доходів бюджету існують два головні аспекти ризикової діяльності - це загрози, пов'язані з надходженням податків та інших видів обов'язкових платежів до бюджету та управлінські загрози, які зумовлені існуючою системою адміністрування доходів. Для мінімізації впливу першої зазначеної групи загроз необхідна побудова раціональної бюджетної системи за оптимального рівня фіскального навантаження. Мінімізацію впливу другої групи загроз уможливить забезпечення ефективної діяльності державних органів адміністрування і контролю.

Визначено фактори, які спричиняють ризики та загрози бюджетних втрат унаслідок порушень у системі управління бюджетними доходами: ризики, при реалізації яких обсяги надходжень до бюджетів не досягатимуть прогнозних розмірів унаслідок неефективності прогнозування і планування доходів бюджету та порушень у процесі оперативної роботи, насамперед у ході мобілізації платежів до бюджету; ризики надвитратності, у випадку реалізації яких витрати на забезпечення прогнозних обсягів надходжень до бюджетів за окремими видами доходів перевищуватимуть економічно доцільні; ризики порушення бюджетного і податкового законодавства та ризики власне адміністрування бюджетних доходів.

Ключові слова: бюджетна безпека, загрози бюджетній безпеці, бюджетна система, державний борг, дефіиит державного бюджету.

Bibliographic description for quoting:

Bondaruk, T. H., Momotiuk, L. Ye., \& Bondaruk, O. S. (2020). Budget Security as Factor of Economic Development of the State. Statystyka Ukrainy - Statistics of Ukraine, 2-3, 40-47. Doi: 10.31767/su.2-3(89-90)2020.02-03.05.

Бібліографічний опис для цитування:

Бондарук Т. Г., Момотюк Л. С. Бондарук О. С. Бюджетна безпека як фактор економічного розвитку держави (публікується англійською мовою). Статистика Украйни. 2020. № 2-3. С. $40-47$. Doi: 10.31767/su.2-3(89-90)2020.02-03.05. 